УДК 159.973: $376.42+372.3$

DOI https://doi.org/10.32782/apv/2021.3.29

\title{
Оксана БОРЯК
}

доктор педагогічних наук, дочент, професор кафедри спеиіальної та інклюзивної освіти, Сумський державний педагогічний університет імені А. С. Макаренка, вул. Роменська, 87, Суми, Україна, 40002 ORCID: 0000-0003-2484-1237

\section{Анна ЧОБАНЯН}

кандидат психологічних наук, стариий викладач кафедри спеціальної та інклюзивної освіти, Сумський державний педагогічний університет імені А. С. Макаренка, вул. Роменська, 87, Суми, Украӥна, 40002

ORCID: 0000-0001-6191-1068

Бібліографічний опис статті: Боряк, О., Чобанян, А. (2021) Дослідження сформованості показників психічного здоров’я дошкільників з інтелектуальними порушеннями. Acta Paedagogica Volynienses, 3, 199-204, doi: https://doi.org/10.32782/apv/2021.3.29

\section{ДОСЛІДЖЕННЯ СФОРМОВАНОСТІ ПОКАЗНИКІВ ПСИХІЧНОГО ЗДОРОВ’Я ДОШКІЛЬНИКІВ 3 ІНТЕЛЕКТУАЛЬНИМИ ПОРУШЕННЯМИ}

Авторками статті на основі порівняльного аналізу даних за результатами емпіричного дослідження виявлено специфіку сформованості показників психічного здоров'я старших дошкільників розумовою відсталістю, що конкретизується в низькому рівні сформованості обох критеріїв (соиіально-особистісного/емоиійно-поведінкового). У межах статті конкретизовано, щзо становлення психічного здоров'я на тлі розумової відсталості дітей дошкільного віку зумовлено низьким рівнем усвідомлення дитиною себе як члена сочіальної групи, несформованою здатністю сприймати та продукувати інформачію про себе, свої вподобання, значущих дорослих, неспроможністю дотримання соціальних норм та ичінностей у поведінці, високому рівні тривожності, наявних агресивних тендениій, відсутності самостійності й безпорадності щуодо надання допомоги іншим, очікуванні допомоги з боку дорослих, неадекватності емоційно-бурхливих реакиій, щэо супроводжуються частими змінами настрою, прагненнями до усамітнення.

Дослідничі висувають припущееня про переважання постнатального періоду розвитку, як першочергового фактора впливу на становлення психічного здоров'я дошкільника. В иььому аспекті актуальності набуває підвищення виховного потенціалу матері (батьків/осіб, щчо їх замімують) на потребу формування/розвитку визначених показників психічного здоров'я розумово відсталих дітей.

Отримані результати підтверджують зумовленість виникнення розумової відсталості негативними чинниками пренатального, натального та постнатального етапів розвитку. Важливо саме у дошкільному віці правильно діагностувати існуючі прояви порушень показників психічного здоров'я, для впровадження відповідних заходів для їх виправлення та розвитку. Подальші дослідження повинні визначити взаємодію інтелектуальних порушень до виявлених підвищених показників порушень психічного здоров'я.

Ключові слова: психічне здоров'я, нормотиповий розвиток, порушення психофізичного розвитку, розумово відсталі діти.

\section{Oksana BORIAK}

Doctor of Pedagogical Sciences, Assistant Professor, Professor at the Department of the Special and Inclusive Education, Sumy A. S. Makarenko State Pedagogical University, Romenska str., 87, Sumy, Ukraine, 40002 ORCID: 0000-0003-2484-1237

\section{Anna CHOBANIAN}

Candidate of Psychology Sciences (Special Psychology), Senior Lecturer at the Department of the Special and Inclusive Education, Sumy A. S. Makarenko State Pedagogical University, Romenska str., 87, Sumy, Ukraine, 40002

ORCID: 0000-0001-6191-1068

To cite this article: Boriak, O., Chobanian, A. (2021). Doslidzhennia sformovanosti pokaznykiv psykhichnoho zdorovia doshkilnykiv z intelektualnymy porushenniamy [Study mental health indicators in preschoolers with intellectual disorders]. Acta Paedagogica Volynienses, 3, 199-204, doi: https://doi.org/10.32782/apv/2021.3.29 


\section{STUDY MENTAL HEALTH INDICATORS IN PRESCHOOLERS WITH INTELLECTUAL DISORDERS}

The authors of the article based on a comparative analysis of data based on empirical research revealed the specifics of the formation of mental health indicators of older preschoolers mental retardation, which is specified in the low level of formation of both criteria (socio-personal / emotional-behavioral). Within the limits of the article, it is specified that the formation of mental health on the background of mental retardation of preschool children is due to low level of selfawareness as a member of a social group, unformed ability to perceive and produce information about themselves, their preferences, meaningful adults. behavior, highlevels of anxiety, aggressive tendencies, lack of independence and helplessness in helping others, expectation of help from adults, inadequacy of emotionally violent reactions, accompanied by frequent mood swings, the desire for solitude.

Researchers make assumptions on the predominance of the postnatal period of development, as a primary factor influencing the formation of mental health of the preschooler. In this aspect, the increase in the educational potential of the mother (parents / persons replacing them) for the formation / development of certain indicators of mental health of mentally retarded children and postnatal stages of development. It is important to correctly diagnose the existing manifestations of mental health disorders in preschool age, to implement appropriate measures for their correction and development. Further research should determine the interaction of intellectual disabilities to the identified elevated rates of mental health disorders.

Key words: mental health, normative development, psychophysical development disorders, prenatal, mentally retarded children.

Актуальність проблеми. Стан психічного здоров'я дітей із порушеннями психофізичного розвитку - гостра проблема сьогодення. У сучасних виданнях трактування психічного здоров'я особистості зводиться до успішного виконання психічної функції, результатом якої $€$ продуктивна діяльність, встановлення відносин 3 іншими людьми і здатність адаптуватися до змін і справлятися 3 несприятливими життєвими обставинами (J. Barling \& J. Staniszkis, 2010). Проблематика психічного здоров'я при нормотиповому та порушеному розвитку тривалий час залишається гострим питанням як для науковців, так і для практиків: психічне здоров'я дорослих з розумовою відсталістю (Е. Emerson \& C. Hatton, 2007), психічні розлади у дорослих з обмеженими інтелектуальними можливостями (S.-A. Cooper, E. Smiley, J. Morrison, 2007).

Аналіз останніх досліджень і публікацій. Наукова розвідка з обраної теми дослідження підтверджує та доповнює дані про зумовленість психічного здоров'я розумово відсталих дітей. Науковці дійшли висновків про те, що розумова відсталість зумовлюе появу трьох найпоширеніших категорій психічних розладів (поведінкові, емоційні, включаючи тривожний розлад, та гіперкінези). Показники поширеності трьох категорій психічних розладів були суттєво вищими серед розумово відсталих дітей, детермінантами визначено: інтелектуальне порушення, вік дитини, стать дитини (чоловіча), погане фізичне/психічне здоров'я матері, відсутність освітньої кваліфікації матері (E. Emerson, C. Hatton, 2007).
Актуальним є дослідження щодо співіснування психічних розладів з інтелектуальною недостатністю у дітей віком від 3 до 18 років (R. Lakhan, 2013). Серед психічних розладів дітей із інтелектуальною недостатністю виявлено поведінкові проблеми, енурез, розлади дефіциту уваги і гіперактивність, тривожність, депресію. Поширеність психічних розладів була статистично вищою серед дітей 3 помірною та тяжкою розумовою відсталістю, ніж серед дітей з легким інтелектуальним порушенням.

Дослідження щодо інтеграції соціальних, психологічних та генетичних впливів на інтелектуальні порушення дітей та їхній вплив на психічне здоров'я батьків (K. Baker, R.T. Devine, E. Ng-Cordell, F. Lucy Raymond, C. Hughes, 2020) довело, що показники фізичного здоров'я батьків виступають важливим предиктором психічного здоров'я дітей і мають підвищену значущість для батьків із успадкованими геномними варіантами.

Утім, ці дослідження виконано на різному методологічному підгрунті й поза достатньою увагою залишилося питання психічного здоров'я дошкільників 3 розумовою відсталістю. Специфіка порушень психічного здоров'я у них характеризується, перш за все, тотальним недорозвиненням вищих кіркових функцій, інертністю психічних процесів, тотальним недорозвиненням пізнавальної діяльності при вираженому стійкому дефіциті абстрактного мислення, процесів узагальнення і відволікання (Лебединський, 2003). Надзви- 
чайно вразливою в цьому аспекті є вікова категорія дошкільників, оскільки показники їхнього психічного здоров'я виступають істотною умовою соціальної стабільності особистості, що $\epsilon$ першочерговим завданням корекційно-розвиткової, навчально-виховної роботи 3 дітьми представленої нозологічної групи.

Мета дослідження - виявлення показників психічного здоров'я розумово відсталих дошкільників за специфікою пренатального, натального та постнатального етапів їх розвитку.

Виклад основного матеріалу дослідження. У ході дослідження було використано наступні методи: аналіз спеціальної медичної, психолого-педагогічної літератури для розкриття сутності детермінант психічного здоров'я старших дошкільників 3 розумовою відсталістю та визначення показників психічного здоров'я; порівняння та систематизація дослідного матеріалу для визначення показників психічного здоров'я дошкільників легкого та помірного ступенів розумової відсталості від ускладнень пренатального, натального та постнатального етапів розвитку; дедуктивний - для системного опису явища, що досліджується; індуктивний - для встановлення закономірностей, систематизації результатів емпіричного дослідження; діагностичний комплекс для виявлення особливостей показників психічного здоров' я - «Методика оцінки рівня соціального розвитку» (за А. Закрепіною) дала змогу визначити рівень сфоромованості соціального інтелекту, знань про себе та своє місце у світі, уявлень про соціальні норми, правила, розуміння соціальної дійсності, співробітництва; проективна методика тестування: «Будинок, дерево, людина» (за Дж. Буком) у межах якого використовувалася бальна система, яка дозволила оцінити психоемоційний стан дитини за такими симптомокомплексами: ворожість; конфліктність; агресивність; негативізм; комплекс меншовартості, методика «Спільне сортування» (за Г. Бурменською), дозволила дослідити адекватність взаємодії дітей з розумовою відсталістю 3 однолітками та дорослими. Кутове перетворення Фішера (критерій $\varphi^{*}$ ).

Вибірка дослідження становила 448 дітей дошкільного віку, з яких - 292 дошкільники 3 розумовою відсталістю помірного ступеня та 156 - дошкільник із розумовою відсталістю легкого ступеня.
У ході проведення збору анамнестичних даних були одержані такі результати. У 17,5\% це були перші діти в сім’і, що народилися від першої вагітності матері; у 45,7\% діти народилися від другої-третьої вагітності матері; $36,8 \%$ - від 4 і більше, при цьому в більшості випадків це були перші діти в сім’ї. Кількість балів за шкалою Апгар у 89,5\% дітей становила від 4 до 6 балів.

Було виявлено випадки, що ймовірно спричинили виникнення розумової відсталості на ранніх етапах життя (віком до трьох років) ускладнення після щеплень (18,9\%), інфекційні захворювання (менінгіт, тяжкі форми стафілококів, коклюшу) - 29,7\%. У 32,7\% розумова відсталість нез' ясованої генези.

Спираючись на ретроспективний аналіз історій хвороб, клінічних висновків, додаткових медичних (неврологічних) обстежень, анамнестичних даних дошкільників, ми виявили низку системних порушень раннього розвитку: у всіх дітей має місце в більшому чи меншому ступені виражена затримка психомоторного розвитку, передусім - затримка в розвитку рухових функцій. Ці діти починають тримати головку у віці після п'яти місяців, сидіти - після року, як правило, вони самостійно не оволодівають рухами перевертання зі спинки на живіт і навпаки; формування хапальних рухів виникає після року-півтора.

За результатами обробки медико-психолого-педагогічної документації (медичних карт, медичних висновків, карт здоров'я) було встановлено:

Супутні порушення розумової відсталості при легкому ступені (F 70.0): неускладнена форма - 86 (55\%); аутистичні порушення (F 84) - 16 (10\%); розлади експресивного мовлення (F 80.1) - 14 (9\%); епілепсія (генералізована) - 14 (9\%); ДЦП - 10 (6,4\%); невроз нав'язливих рухів - $10(6,4 \%)$; хвороба Дауна - 6 (4,2\%).

Виявлені такі супутні порушення при помірному ступені розумової відсталості (F 71.0): неускладнена форма - 178 (61\%), хвороба Дауна - 65 (22,2\%), невроз нав'язливих рухів - $33(11,3 \%)$, порушення спектру аутизму (F 84) - 16 (5,5\%). Розлади експресивного мовлення (F 80.1) виявлено в 197 (67,5\%) від загальної кількості дітей із помірним ступенем розумової відсталості. 


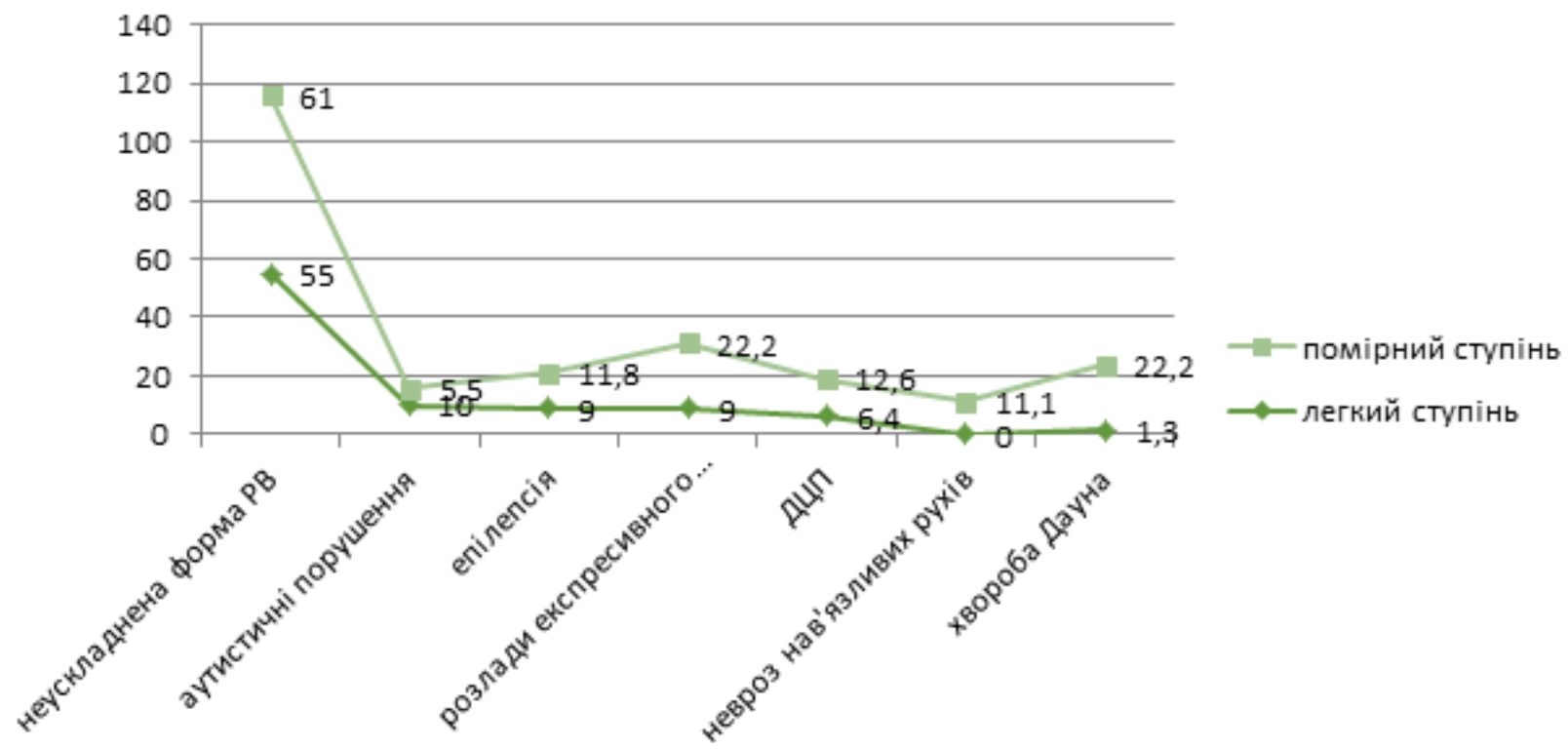

Рис. 1. Результати виявлення супутньої симптоматики порушень розвитку розумово відсталих дошкільників (у \%)

Розподіл дітей за супутньою симптоматикою порушень розвитку подано на діаграмі (рис. 1).

Узагальнюючи викладене вище, можемо зазначити, що загальною ознакою, притаманною всім дітям, є тотальна затримка психомоторного та мовленнєвого розвитку. В етіології інтелектуальних, мовленнєвих та інших супутніх порушень визначаємо суттєвий вплив на стан психічного здоров'я дітей патологічного перебігу вагітності та $\dddot{1}$ ускладненнями.

Першим критерієм, який досліджувався, був соціально-особистісний за «Методикою оцінки рівня соціального розвитку» (А. Закрепіна). Результати свідчать, що у дітей обох груп з розумовою відсталістю спостерігається низький рівень сформованості сочіальноособистісного критерію (помірна розумова відсталість $=52,8 \%$ проти легкої розумової відсталості $=26,8 \varphi^{*}=1,89$, що відповідає $\rho \leq 0,02)$ за рахунок низьких показників сформованості: уявлень про себе (помірний cmуniнь $=23,7 \%$ проти легкої $=51,2 \%$ при $\rho \leq 0,02$ ), уявлень про інших (помірний стуnінь $=16,9 \%$ проти легкого ступеня $=56,1 \%$ при $\rho \leq 0,01)$, розуміння соціальної дійсності основ співробітництва (помірний ступінь = $15,8 \%$ проти легкого ступеня $=39,1 \%$ при $\rho \leq 0,02)$ (табл. 1).

Було з'ясовано, що постнатальний період відіграє суттєву роль у входженні розумово відсталої дитини в соціум. Існує сталий харак- тер зв'язку між дітьми обраної категорії та їх батьками на різних етапах онтогенезу, на відміну від системи взаємин батьки - дитина 3 нормотиповим розвитком. Ця особливість зумовлює посилення значимості ролі батьків, зокрема як прикладів для наслідування їх соціальної поведінки та як учасників процесу соціального життя.

Таблиця 1

Результати вивчення рівнів сформованості соціального особистісного критерію (у \%)

\begin{tabular}{|c|c|c|}
\hline Рівні & $\begin{array}{c}\text { Дошкільники } \\
\text { з розумовою від- } \\
\text { сталістю помірного } \\
\text { ступеня }\end{array}$ & $\begin{array}{c}\text { Дошкільники } \\
\text { з розумовою від- } \\
\text { сталістю легкого } \\
\text { ступеня }\end{array}$ \\
\hline Високий & - & 3,2 \\
\hline Середній & 24,5 & 53,6 \\
\hline Низький & 52,8 & 26,8 \\
\hline Нульовий & 22,7 & - \\
\hline
\end{tabular}

Другим критерієм дослідження став емоційно-поведінковий. Результати засвідчила також низькі показники сформованості емоційно-поведінкового критерію показників психічного здоров'я дошкільників 3 розумовою відсталістю обох груп.

Установлено низьку сформованість емоційно-поведінкового критерію показників психічного здоров'я (нульовий рівень у помірного ступеню $=52,8 \%$ проти легкого ступеня $=20,7 \%$ при $\rho \leq 0,02)$, що конкретизується в низькій продуктивності спільної 
діяльності, наявності комплексу меншовартості, підвищеній тривожності та схильності до усамітнення (у $64,1 \% \varphi^{*}=1,91$ при $\rho \leq 0,02)$, невмінні домовлятися з оточуючими (у 73,5\% $\varphi^{*}=2,07$ при $\rho \leq 0,01$ ), високому рівні агресивності, негативізму, відсутності самостійності й безпорадності щодо надання допомоги іншим, очікуванні допомоги з боку дорослих (у 73,5\% $\varphi^{*}=2,07$ при $\rho \leq 0,01$ ), неадекватності емоційно-бурхливих реакцій, що супроводжуються частими змінами настрою (у $64,1 \% \varphi^{*}=1,92$ при $\rho \leq 0,02$ ), проявами неадекватності поведінки в незнайомих умовах (65\% при $\rho \leq 0,01)$ Зведені показники дослідження подано у таблиці (табл. 2).

\section{Таблиця 2}

Результати вивчення рівнів сформованості емоційно-поведінкового критерію (у \%)

\begin{tabular}{|c|c|c|}
\hline Рівні & $\begin{array}{c}\text { Дошкільники } \\
\text { з розумовою від- } \\
\text { сталістю помірного } \\
\text { ступеня }\end{array}$ & $\begin{array}{c}\text { Дошкільники } \\
\text { з розумовою від- } \\
\text { сталістю легкого } \\
\text { ступеня }\end{array}$ \\
\hline Високий & - & - \\
\hline Середній & 16,9 & 28,3 \\
\hline Низький & 30,3 & 51 \\
\hline Нульовий & 52,8 & 20,7 \\
\hline
\end{tabular}

Отримані дані засвідчують, що події пренатального/натального періоду накладають значний відбиток на подальше життя дитини. Достеменним фактом, $\epsilon$ підтвердження тісної взаємодії між матір'ю і ще ненародженою дитиною (дитина вчиться сприймати світ разом із матір'ю). Виражена тривожність породіллі, страхи щодо очікування пологів/їхнього ускладнення, зумовлюють виникнення аналогічних за своєю спрямованістю емоційних станів дитини (Сюсюка, Котлова, 2014).

Проте, для відносно гармонійного психічного здоров'я та соціального функціонування дитини 3 розумовою відсталістю надважливе значення має поведінка матері і після народження дитини.

Висновки іперспективи подальших досліджень. На основі порівняльного аналізу даних за результатами емпіричного дослідження виявлено специфіку сформованості показників психічного здоров'я старших дошкільників розумовою відсталістю, що конкретизується в низькому рівні сформованості обох критеріїв. Загалом, можемо констатувати, що ста- новлення психічного здоров'я на тлі розумової відсталості дітей дошкільного віку зумовлено низьким рівнем усвідомлення дитиною себе як члена соціальної групи, несформованою здатністю сприймати та продукувати інформацію про себе, свої вподобання, значущих дорослих, неспроможністю дотримання соціальних норм та цінностей у поведінці, високому рівні тривожності, наявних агресивних тенденцій, відсутності самостійності й безпорадності щодо надання допомоги іншим, очікуванні допомоги 3 боку дорослих, неадекватності емоційно-бурхливих реакцій, що супроводжуються частими змінами настрою, прагненнями до усамітнення.

Робимо припущення про переважання постнатального періоду розвитку, як першочергового фактора впливу на становлення психічного здоров'я дошкільника. В цьому аспекті актуальності набуває підвищення виховного потенціалу матері (батьків/осіб, що їх заміщують) на потребу формування/розвитку визначених показників психічного здоров'я розумово відсталих дітей.

Отримані результати підтверджують зумовленість виникнення розумової відсталості негативними чинниками пренатального, натального та постнатального етапів розвитку. Важливо саме у дошкільному віці правильно діагностувати існуючі прояви порушень показників психічного здоров'я, для впровадження відповідних заходів для їх виправлення та розвитку. Ці прояви порушень детермінують 3 негативними чинниками зазначених етапів розвитку. Доведено тяжкість проявів порушень психічного здоров'я: детермінанти пренатального, натального етапів розвитку зумовлюють більш глибокі комплексні прояви порушень психічного здоров'я.

Подальші дослідження повинні визначити відносний внесок (та взаємодію) інтелектуальних порушень, соціальні / екологічні фактори, психологічні фактори та біологічні фактори до виявлених підвищених показників порушень психічного здоров'я. Дослідження в цьому напрямі буде вимагати використання більш складних та довготривалих експериментальних дослідницьких проектів, використання наявних методів або розробки нових методологічних підходів у психопатології, що засто- 
совуються до дітей з розумовою відсталістю розумового розвитку.

Вивчення взаємодії між біологічними та соціальними факторами пренатального, натального та постнатального розвитку також потребуватимуть посиленої акцентуації на міждисциплінарних дослідженнях, які заповнюють розрив між соціальною епідеміологією та поведінковою генетикою.

\section{ЛIТЕРАТУРА:}

1. Закрепина А. Изучение особенностей социального развития детей дошкольного возраста с отклонениями в умственном развитии. Дошкольное воспитание. 2010. № 1. С. 66-73.

2. Романова Е.С. Графические методы в практической психологии. Санкт-Петербург : Речь, 2001. 529 с.

3. Лебединский В.В. Нарушения психического развития в детском возрасте : учеб. пособие для студ. психол. фак. высш. учеб. заведений. Москва : Издательский центр «Академия», 2003. 144 с.

4. Сюсюка В.Г., Котлова Ю.В. Вплив тривожності жінок під час вагітності на стан новонароджених та перебіг їх раннього неонатального періоду. Актуальні питання педіатрії, акушерства та гінекології. 2014. № 1. С. 117-120.

5. Barling, J. History of occupational health psychology. In: J.C. Quick, L.E. Tetrick (Eds.) [2nd ed.] Washington, DC : APA Books, 2010. P. 21-34.

6. Emerson E., Hatton C. Mental health of children and adolescents with intellectual disabilities in britain. The British Journal of Psychiatry 2007. № 191. P. 493-499.

7. Cooper S.-A., Smiley E., Morrison J. et al. Mental ill-health in adults with intellectual disabilities: prevalence and associated factors. The British Journal of Psychiatry 2007. № 190. P. $27-35$.

8. Lakhan R. The Coexistence of Psychiatric Disorders and Intellectual Disability in Children Aged 3-18 Years in the Barwani District, India. Hindawi Publishing Corporation ISRN Psychiatry Volume 2013, Article ID 875873, 6 pages.

9. Baker K., Devine R.T., Ng-Cordell E. et al. Childhood intellectual disability and parents' mental health: integrating social, psychological and genetic influences. IMAGINE-ID consortium and Claire Hughes. The British Journal of Psychiatry. 2020. Page 1 of 8.

\section{REFERENCES:}

1. Zakrepina A. (2010) Study of the peculiarities of social development of mentally retarded preschoolers. Preschool education. No. 1: p. 66-73.

2. Romanova E.S. (2001). Graphic methods in practical psychology. Saint Petersburg.: Rech, 529 p.

3. Lebedinsky V.V. (2003). Disorders of mental development in childhood: textbook for students of the psychological faculty of higher educational establishments. Moscow: Akademiya; $144 \mathrm{p}$.

4. Siusiuka V.H., Kotlova Yu.V. (2014). Influence of anxiety of women during pregnancy on the condition of newborns and the course of their early neonatal period. Current issues of pediatrics, obstetrics and gynecology. No. 1: p. 117-120.

5. Barling J. (2010). History of occupational health psychology. In: J.C. Quick, L.E. Tetrick (Eds.). [2nd ed.]. Washington, DC: APA Books. p. 21-34.

6. Emerson E., Hatton C. (2007). Mental health of children and adolescents with intellectual disabilities in britain. The British Journal of Psychiatry. P. 493-499.

7. Cooper S.-A., Smiley E., Morrison J. (2007). Mental ill-health in adults with intellectual disabilities: prevalence and associated factors. The British Journal of Psychiatry. P. 190: 27-35.

8. Lakhan R. (2013). The Coexistence of Psychiatric Disorders and Intellectual Disability in Children Aged 3-18 Years in the Barwani District, India. Hindawi Publishing Corporation ISRN Psychiatry Volume, Article ID 875873, 6 pages.

9. Baker K., Devine R. T., Ng-Cordell E. (2020). Childhood intellectual disability and parents'mental health: integrating social, psychological and genetic influences. IMAGINE-ID consortium and Claire Hughes. The British Journal of Psychiatry Page 1 of 8 . 